\title{
Overactive bladder - 18 years - Part II
}

Jose Carlos Truzzi ${ }^{1}$, Cristiano Mendes Gomes ${ }^{2}$, Carlos A. Bezerra ${ }^{3}$, Ivan Mauricio Plata ${ }^{4}$, Jose Campos ${ }^{5}$, Gustavo Luis Garrido ${ }^{6}$, Fernando G. Almeida ${ }^{1}$, Marcio Augusto Averbeck ${ }^{7}$, Alexandre Fornari ${ }^{8}$, Anibal Salazar ${ }^{9}$, Arturo Dell'Oro ${ }^{10}$, Caio Cintra ${ }^{3}$, Carlos Alberto Ricetto Sacomani ${ }^{9}$, Juan Pablo Tapia ${ }^{11}$, Eduardo Brambila ${ }^{12}$, Emilio Miguel Longo ${ }^{13}$, Flavio Trigo Rocha ${ }^{2}$, Francisco Coutinho ${ }^{12}$, Gabriel Favre ${ }^{14}$, José Antonio Garcia ${ }^{14}$, Juan Castaño ${ }^{15}$, Miguel Reyes ${ }^{12}$, Rodrigo Eugenio Leyton ${ }^{16}$, Ruiter Silva Ferreira ${ }^{17}$, Sergio Duran ${ }^{12}$, Vanda López ${ }^{18}$, Ricardo Reges ${ }^{19}$

${ }^{1}$ Escola Paulista de Medicina - EPM - Universidade Federal de São Paulo, SP, Brasil; ${ }^{2}$ Departamento de Urologia, Universidade de São Paulo, SP, Brasil; ${ }^{3}$ Departamento de Urologia, Faculdade de Medicina do ABC, SP, Brasi; ${ }^{4}$ Departamento de Urología, Universidad de los Andes, Bogota, Colombia; ${ }^{5}$ Departamento de Urología, Escuela Médico Militar, Cidade do México, Mexico; ${ }^{6}$ Cátedra de Urologia, Hospital de Clinicas "José de San Martín”, Buenos Aires, Argentina; ${ }^{7}$ Departamento de Urologia, Mãe de Deus Center Hospital, Porto Alegre, RS, Brasil; ${ }^{8}$ Universidade Federal de Ciências da Saúde de Porto Alegre, Porto Alegre, RS, Brasil; ${ }^{9}$ Departamento de Urologia, AC Camargo Hospital, SP, Brasil; ${ }^{10}$ Hospital Clinico de la Fuerza Area de Chile, Santiago, Chile; ${ }^{11}$ Instituto Mexicano del Seguro Social, Ciudad de Mexico, Mexico; ${ }^{12}$ Departamento de Urologia, Hospital Souza Aguiar, RJ, Brasil; ${ }^{13}$ Servicio de Urología, del Complejo Médico Policial Churruca Visca, Buenos Aires, Argentina; ${ }^{14}$ Centro Policlínico Valencia "La Viña”, Valencia, Venezuela; ${ }^{15}$ Hospital Pablo Tobón Uribe, Medellin, Colômbia; ${ }^{16}$ Servicio de Urología, Clinica Indisa, Providencia, Chile; ${ }^{17}$ Centro de Reabilitação e Readaptação Dr. Henrique Santillo, Goiânia, Brasil; ${ }^{18}$ Servicio de Urología, del Hospital Universitario de Caracas, Caracas, Venezuela; ${ }^{19}$ Divisão de Urologia, Universidade Federal do Ceará, CE, Brasil

\section{ABSTRACT}

Traditionally, the treatment of overactive bladder syndrome has been based on the use of oral medications with the purpose of reestablishing the detrusor stability. The recent better understanding of the urothelial physiology fostered conceptual changes, and the oral anticholinergics - pillars of the overactive bladder pharmacotherapy - started to be not only recognized for their properties of inhibiting the detrusor contractile activity, but also their action on the bladder afference, and therefore, on the reduction of the symptoms that constitute the syndrome. Beta-adrenergic agonists, which were recently added to the list of drugs for the treatment of overactive bladder, still wait for a definitive positioning - as either a second-line therapy or an adjuvant to oral anticholinergics. Conservative treatment failure, whether due to unsatisfactory results or the presence of adverse side effects, define it as refractory overactive bladder. In this context, the intravesical injection of botulinum toxin type A emerged as an effective option for the existing gap between the primary measures and more complex procedures such as bladder augmentation. Sacral neuromodulation, described three decades ago, had its indication reinforced in this overactive bladder era. Likewise, the electric stimulation of the tibial nerve is now a minimally invasive alternative to treat those with refractory overactive bladder. The results of the systematic literature review on the oral pharmacological treatment and the treatment of refractory overactive bladder gave rise to this second part of the review article Overactive Bladder - 18 years, prepared during the $1^{\text {st }}$ Latin-American Consultation on Overactive Bladder.

\section{ARTICLE INFO}

\section{Key words:}

Overactive Bladder; Muscarinic

Antagonists; Beta-adrenergic

agonists; Botulinum Toxin; Sacral neuromodulation; Urodynamics

Int Braz J Urol. 2016; 42: 199-214

Submitted for publication:

July 09, 2015

Accepted after revision:

September 09, 2015 


\section{INTRODUCTION}

This second part of the review article Overactive Bladder $(O A B)$ - 18 years will address the oral pharmacological treatment and the treatment of refractory overactive bladder. A large number of studies on basic sciences gave rise to conceptual changes in the treatment of $\mathrm{OAB}$. The urothelium - for decades viewed as a simple interface between the detrusor muscle wall and the urinary content - took a critical position in the pathophysiology and therapeutics of OAB. The identification of pharmacologic receptors, interconnected by a complex neurotransmitter network allowed for a better understanding of the role of neural afference in $\mathrm{OAB}$. Oral anticholinergic agents, used by focusing on efference, started to be recognized for their parallel action on the modulation of bladder filling sensations. A new therapeutic option, still with a limited number of studies - beta-adrenergic agonists - were integrated to the armamentarium of oral medications.

Electrical stimulation of the tibial nerve strengthened the physiotherapeutic measures, now focusing on non-responsive cases to primary behavioral approaches and oral medications. Like oral anticholinergic agents, bolutinum toxin type A had its action initially based on the neuromuscular cholinergic blockage and consequent inhibition of the detrusor overactivity. Once again, recent advances on the urothelium physiology led to the recognition of a number of botulinum toxin actions on receptors that have a direct action on the bladder afference. This stimulated the expansion its use from neurogenic cases to $\mathrm{OAB}$ patients with or without detrusor overactivity. In parallel, sacral neuromodulation had its indication strengthened for the treatment of refractory $\mathrm{OAB}$, although still in a restricted manner in our community.

Ninety-seven of 2,508 publications previously surveyed in the medical literature for the period from 1997 to 2014 were selected by two independent investigators, as described in the first part of this review. Table 1 outlines the keywords used and the details of the selection of articles. Only full texts in English, Spanish and Portuguese were included. Articles only containing abstracts or published in annals of congresses were excluded. In cases of similar publications, the most recent one and showing the highest level of scientific evidence was selected.

The articles were reviewed and their results compiled during the 1st Latin-American Consultation on Overactive Bladder. The present text was prepared from the works presented in a plenary session of the event with the participation of all members of the Consultation.

Overactive bladder management with oral medications

Antimuscarinic agents are for many years the first pharmacological treatment option for overactive bladder. Yet, many safety and tolerability-related aspects limit their use (1-4). Special attention should be given to the interaction of antimuscarinic agents with other drugs commonly used by the elderly, prescribed by cardiologists, general practitioners, and psychiatrists. Many of these drugs either have anticholinergic effects or may interfere with the hepatic metabolism and thereby enhance the adverse effects of the antimuscarinic agents that are used in the treatment of overactive bladder.

Five subtypes of muscarinic receptors are found in the human body, classified as M1, M2, M3, M4, and M5. The smooth detrusor muscle and the urothelium mainly contain M2 and M3 receptors. In the urinary tract, while there is a higher proportion of $\mathrm{M} 2$ receptors, M3 receptors are responsible for bladder contraction. M2 and M3 receptors are also found in other human organs, such as salivary glands and bowel, which may result in adverse reactions from treatments with antimuscarinic agents (4-7).

Some pharmacokinetic characteristics of the antimuscarinic agents are important in the genesis of side effects, such as the ability to cross the blood-brain barrier determined by the molecular weight and level of liposolubility or lipophilicity $(2,4,7)$. In turn, the affinity (pKi) with each receptor also determines differences in the clinical effects. Antimuscarinic agents with lower affinity to M1 receptors (abundant in the central nervous system) provide low risks of neurological adverse effects, even if they cross the blood-brain barrier. In contrast, those with affinity to 
Table 1 - Method of search of scientific publication at PubMed, Bireme

\begin{tabular}{|c|c|c|c|c|}
\hline Groupst & Strategy of search & Filters & $\begin{array}{l}\text { Total of } \\
\text { identified } \\
\text { articles }\end{array}$ & $\begin{array}{l}\text { Total of } \\
\text { selected } \\
\text { articles }\end{array}$ \\
\hline $\begin{array}{l}\text { Concept and diagnosis of } \\
\text { Overactive bladder }\end{array}$ & $\begin{array}{l}\text { ( "Urinary Bladder, Overactive/ } \\
\text { classification"[Mesh] OR } \\
\text { "Urinary Bladder, Overactive/ } \\
\text { diagnosis"[Mesh] OR "Urinary } \\
\text { Bladder, Overactive/etiology"[Mesh] } \\
\text { OR "Urinary Bladder, Overactive/ } \\
\text { pathology"[Mesh] OR } \\
\text { "Urinary Bladder, Overactive/ } \\
\text { physiopathology"[Mesh] ) OR } \\
\text { ( "Urinary Incontinence, Urge/ } \\
\text { classification"[Mesh] OR } \\
\text { "Urinary Incontinence, Urge/ } \\
\text { diagnosis"[Mesh] OR "Urinary } \\
\text { Incontinence, Urge/etiology"[Mesh] } \\
\text { OR "Urinary Incontinence, } \\
\text { Urge/pathology"[Mesh] OR } \\
\text { "Urinary Incontinence, Urge/ } \\
\text { physiopathology"[Mesh] ) }\end{array}$ & $\begin{array}{c}\text { English/spanish/portuguese } \\
+ \text { abstract available }+ \\
01 / 01 / 1985 \text { a } 31 / 05 / 2014+ \\
\text { humans }+>19 \text { years }\end{array}$ & 799 & 53 \\
\hline Epidemiology & $\begin{array}{l}\text { (Urinary Incontinence, Urge or } \\
\text { Urinary Bladder, Overactive) and } \\
\text { (economics or epidemiology) }\end{array}$ & $\begin{array}{c}\text { English/spanish/portuguese } \\
+ \text { abstract available + } \\
01 / 01 / 1985 \text { a } 31 / 05 / 2014+ \\
\text { humans }+>19 \text { anos }\end{array}$ & 713 & 51 \\
\hline Conservative & & & & 35 \\
\hline $\begin{array}{l}\text { Non-Pharmacological } \\
\text { Management }\end{array}$ & $\begin{array}{l}\text { (Urinary Incontinence, Urge or } \\
\text { Urinary Bladder, Overactive) and } \\
\text { (diet theraby or drua theraby }\end{array}$ & $\begin{array}{l}\text { English/spanish/portuguese } \\
+ \text { abstract available + } \\
01 / 01 / 1985 \text { a } 31 / 05 / 2014+\end{array}$ & & \\
\hline Pharmacological Management & $\begin{array}{l}\text { or prevention or control or } \\
\text { rehabilitation or surgery or treatment }\end{array}$ & $\begin{array}{l}\text { humans }+>19 \text { anos } \\
\text { Clinical trials, Review, }\end{array}$ & 996 & 71 \\
\hline $\begin{array}{l}\text { Refractory } \\
\text { Overactive Bladder }\end{array}$ & or therapy) & Randomized Clinical Trial & & 26 \\
\hline
\end{tabular}

M1 muscarinic receptors may trigger cognitive disorders, memory loss, drowsiness, confusion, and even accelerate the emergence of dementias. The drug's ability to interact with $\mathrm{P}$ glycoproteins, which convey substrates into the nerve cell, also works as a determining factor of adverse effects.

Another important characteristic is the drug exposure time, determined by the metabolism in the liver. It is well known that the elderly loses hepatic mass and blood flow, which may reduce the drug elimination via cytochrome CYP3A4, thereby prolonging the permanence of the drug in the blood stream (7).

Several antimuscarinic agents have been studied in the treatment of overactive bladder, including oxybutynin, tolterodine, solifenacin, darifenacin, trospium, fesoterodine and propiverine $(4,6,8-11)$. These drugs mainly have their effects through the inhibition of muscarinic receptors present in the bladder - in both the detrusor muscle 
and the urothelium (10). In turn, they differ from each other in both their molecular structure and pharmacokinetic proprieties, which leads to differences in their clinical effects $(4,7)$. The efficacy of the different antimuscarinic agents is very similar, with their main difference lying on their adverse effects.

Several studies having an appropriate methodologic design showed the efficacy of antimuscarinic agents in controlling overactive bladder symptoms. However, adherence to treatment has been an issue, once discontinuation is reported in up to $80 \%$ of patients in a one-year follow-up (12). Because overactive bladder is a chronic condition and the long-term treatment with antimuscarinic agents is usually necessary, optimizing the tolerability of the drug is critical in obtaining patient satisfaction. The extended-release (ER) formulations show lower adverse effect rates, probably because they provide more homogeneous plasma concentration levels with lower peaks when compared to immediate-release formulations (13-15).

There are several limiting factors when interpreting and analyzing the results reported by the numerous clinical studies of anticholinergic agents for the treatment of overactive bladder. A relevant factor - reiterated in a number of these studies - is the high frequency of positive response to placebo approximately $30 \%$, which makes the interpretation of results more difficult. Another factor that stands out is the variability of the study populations in terms of severity of symptoms as well as the assessment methods employed in the clinical trials.

\section{Clinical efficacy of antimuscarinic agents in the treatment of overactive bladder}

An extensive review of clinical trials evaluating pharmacological therapies of overactive bladder did not reveal any evidence of clinical efficacy differences among the many studied pharmacological agents (16-81). This finding is consistent with the conclusions of many published systematic reviews and meta-analysis (13, 14, 82-93).

From the studies published, a Cochrane review stands out. It demonstrated that solifenacin was superior to tolterodine in the domain of quality of life, according to information pro- vided by patients about their daily urgency and incontinence symptoms. The tolerance to both drugs were similar. Solifenacin showed equivalent efficacy, but with higher tolerance and quality of life than darifenacin (88). The extended-release (ER) formulations provided higher improvement of quality of life than the immediate-release (IR) ones. When compared to tolterodine-IR, oxybutynin-ER had a similar quality-of-life profile, while solifenacin showed superior efficacy and quality of life. In three trials, fesoterodine showed to be more effective, providing superior quality of life when compared to tolterodine-ER (89).

In the SOLIDAR study, the authors compared the selective antimuscarinic agents solifenacin (5 mg) and darifenacin $(7.5 \mathrm{mg})$. Both showed to be equivalent in the results of reducing overactive bladder symptoms; however, solifenacin was superior in quality of life and satisfaction, with a lower incidence of dry mouth (94).

Applying oxybutynin through transdermal patches resulted in similar improvement to that achieved with the oral use of this agent, just with fewer adverse effects (33). Similar results were observed when transdermal oxybutynin and oral tolterodine ER were compared (34).

\section{What are the adverse effects of antimuscarinic agents?}

Several meta-analyses were designed to evaluate the information provided by clinical trials, specifically regarding adverse effects, which allows us to more easily visualize the safety level of each drug in the distinct presentations and routes of administration.

Chapple et al. (83) conducted a systematic review and meta-analysis of 83 clinical trials in which four formulations were associated with a high risk of discontinuation due to adverse events when compared to placebo - oxybutynin IR, 7.5-10 mg/d; oxybutynin IR, $15 \mathrm{mg} / \mathrm{d}$; propiverine ER, $20 \mathrm{mg} / \mathrm{d}$; and solifenacin, $10 \mathrm{mg} / \mathrm{d}$. Tolterodine ER $4 \mathrm{mg} / \mathrm{d}$ was the only formulation associated with low risk of discontinuation when compared to placebo. Reports of dry mouth of any severity were the most commonly seen with all the interventions, with significant difference when compared to placebo. The relative risk ran- 
ged from 2.1 to 5.9 and increased when the doses of darifenacin, fesoterodine, solifenacin, and tolterodine were increased. This tendency was not evident for oxybutynin and propiverine. Other adverse effects were significantly high with the active treatment when compared to placebo, including: blurred vision, constipation, erythema, fatigue, pruritus, excessive sweating, and urinary retention.

Another meta-analysis on adverse effects showed fewer patients with dry mouth when using ER formulations of oxybutynin and tolterodine when compared to IR formulation of both drugs, with significant results. There were no within-group differences for the different doses of each medication (82).

Trospium chloride, darifenacin and fesoterodine are active substrates for the $\mathrm{P}$ glycoprotein-dependent cell transport system, which means a high reduction of the blood-brain barrier permeability, with low levels in the central nervous system; particularly trospium, which is almost undetectable in the cerebrospinal fluid and a good option in patients with risk of cognitive worsening due to a number of neurological pathologies, such as Parkinson's disease, multiple sclerosis, senile dementia, etc. $(95,96)$.

A randomized, placebo-controlled, double-blind study compared the effects of oxybutynin topic gel, with oral IR oxybutynin and placebo on the cognitive and psychomotor functions in healthy elder patients (97). When compared to the oral IR formulation, oxybutynin gel has equivalent efficiency, with reduced side effects and a clinically significant effect of less worsening of the cognitive function in healthy older subjects.

Recently, Kessler et al. (98) revealed great methodological and statistic creativity - which they compiled in a systematic review - by using a new meta-analysis referred to as "network meta-analysis." Through this, after extracting the data from clinical trials, the adverse events were classified into seven categories (gastrointestinal, ocular/ visual, urinary tract-related, neurologic, cardiac, respiratory, and dermatological) of the Common Terminology Criteria for Adverse Events (CTCAE) and scored using the visual analogic scale (VAS): $0=$ minimal severity and $10=$ maximum severity, based on a consensus of ten independent specia- lists. This meta-analysis studied 60 trials involving 26,229 patients and found a similar global adverse effect profile for darifenacin, fesoterodine, transdermal oxybutynin, propiverine, solifenacin, tolterodine, and trospium, but not for oral oxybutynin when compared to the initial dose. Oxybutynin in doses equal or superior to $10 \mathrm{mg} / \mathrm{dL}$ had a worse adverse event profile. Darifenacin, fesoterodine, transdermal oxybutynin, propiverine, and solifenacin showed a significantly better dose-adverse effect correlation. Of all adverse effects, the gastrointestinal ones were the most frequently reported. Only the transdermal oxybutynin at 3.9 $\mathrm{mg} / \mathrm{dL}$ showed a gastrointestinal profile similar to placebo. Its visual/ocular adverse event profile was similar among the antimuscarinic agents when the initial dose was used. The same was observed for the urinary tract, neurologic, cardiac, and respiratory profiles. While the dermatological adverse effects were minor with the oral administration of the drugs, the adverse event profile was worse with the transdermal administration.

The absolute contraindications for the use of antimuscarinic agents include urinary retention, gastric retention, closed-angle glaucoma, and known hypersensitivity to the pharmacological agent. The relative contraindications include partially obstructed bladder emptying, renal or hepatic changes, excessive use of alcohol, reduced gastrointestinal motility, constipation, and myasthenia Gravis (99).

What are the effects of beta-3-adrenergic agonists on overactive bladder symptoms and their adverse effects?

Animal studies and clinical trials have shown that beta-3 agonists relax the detrusor muscle, thereby improving bladder filling and compliance. There is a significant improvement of the incontinence and voiding episodes in 24 hours as well as a significant improvement of the quality of life $(100,101)$.

The beta-3 agonist Mirabegron was approved for the treatment of overactive bladder in Japan in September 2011 and in Europe and the United States in June 2012 (102). Other beta3 agonists, such as Solabegron and TRK-380, are still under investigation $(103,104)$. 
Experimental studies have demonstrated that beta-3 adrenergic receptor ( $\beta 3 \mathrm{AR}$ ) agonists result in relaxation of the smooth detrusor muscle in humans mediated by the stimulation of the enzyme adenyl cyclase, which leads to the accumulation of cyclic adenosine monophosphate (AMPc). In addition, $\beta 3-A R$ activation seems to inhibit detrusor contraction also due to the release of urothelium-derived inhibitory factor (UDIF) $(105,106)$.

Seven clinical studies showed that Mirabegron $(25,50$, and $100 \mathrm{mg})$ results in a significant reduction of urinary incontinence and voiding episodes in 24 hours (107-111). Five of these studies used 4-mg tolterodine ER as the active control group; five were phase III studies conducted to evaluate safety and efficacy, one was a phase II proof-of-concept study (111), and one was a phase II study of dose determination (109). One of the phase III studies included 1,978 patients from 27 European countries and Australia. All three active groups showed improvement when compared to placebo; however, tolterodine was only superior to placebo at week 4 . The main limitation was the short period of 12 weeks of treatment (110).

Another international phase III randomized, placebo-controlled, double-blind, multicenter clinical study conducted in the United States and Canada evaluated the effect of Mirabegron on overactive bladder patients experiencing symptoms for over three months. When compared to placebo, $50 \mathrm{mg}$ and $100 \mathrm{mg}$ Mirabegron resulted in a superior reduction of the number of incontinence and voiding episodes in 24 hours (112).

One study evaluated the urodynamic impact of Mirabegron on bladder emptying in men. In this study, 200 men with lower urinary tract symptoms associated with benign prostatic hyperplasia were randomized to receive $50 \mathrm{mg}$ or 100 $\mathrm{mg}$ of Mirabegron or placebo daily during 12 weeks. There was no significant difference between groups, in terms of urinary flow and the detrusor pressure on the maximum flow (100).

The pooled analysis of three phase III studies revealed that the global incidence of adverse events and serious adverse events was similar among the groups treated with Mirabegron, tolterodine or placebo $(15,113)$.
One study evaluated the potential of Mirabegron to cause a change in the cardiac repolarization in healthy patients. The authors observed that Mirabegron did not prolong the QTc interval at the doses of 50 or $100 \mathrm{mg}$; only the $200 \mathrm{mg}$ dose of Mirabegron caused an increase of the QTC interval superior to $10 \mathrm{~ms}$ in women (114).

Mirabegron dose is recommended to be reduced in patients with renal and hepatic impairment, and because it inhibits CYP enzyme, caution should be taken in patients using digoxin and metoprolol (101).

\section{Treatment of refractory overactive bladder}

Patients that are refractory to conservative treatment, including behavioral, physiotherapeutic and pharmacological treatments should be evaluated by a specialist, in case they want additional treatment.

Patients considered refractory are those failing an adequate behavioral treatment, for long enough to evaluate the results, usually three months, and that have also failed the pharmacological treatment with at least one antimuscarinic agent, taken for at least 4-8 weeks. Pharmacological treatment failure may include lack of efficacy, drug intolerance, or absolute contraindication to its use.

Treatment options after failure of conservative treatment pose significant risks to patients. Therefore, before indicating such treatments, a thorough evaluation should take place in order to ensure that the complaints are truly resulting from idiopathic overactive bladder, rather than secondary to other clinical conditions.

The therapeutic options after conservative treatment failure include electrical stimulation of the tibial nerve, botulinum toxin injection into detrusor, and sacral neuromodulation (SNM). Each of these alternatives has advantages and disadvantages that will be addressed in the respective topic.

The use of these therapeutic options requires a careful selection of patients and detailed education. Such treatments may be offered in any order; that is, none of them could be considered as being superior to the others. If a patient fail in one of these treatments, he or she can be a candidate to another one. The efficacy of a combination of these therapeutic modalities is unknown. 


\section{Electrical stimulation of the tibial nerve}

The peripheral electrical stimulation of the tibial nerve has been used in the treatment of bladder filling and urgency urinary incontinence symptoms. The impact of the treatment depends on the severity of the symptoms before treatment, the number of weekly sessions, and the evaluation time point following the procedure. This technique can be performed transcutaneously or percutaneously (115). The electrical stimulation has its effect by inhibiting the detrusor activity via afferent action of the pudendum nerve (116). In order to stimulate the tibial nerve percutaneously (PTNS), a 34G needle is inserted in a cephalic position in relation to the internal malleolus and for electrical stimulation, a low voltage $(9 \mathrm{~V})$ with a width of $0-10 \mathrm{~mA}$ is used, with a fixed frequency of $20 \mathrm{~Hz}$ and pulse width of $200 \mathrm{~ms}$. The majority of the studies evaluating this therapeutic modality is of case sequences, without a control group, and exclusively conducted in women. The equipment, as well as the electrical stimulation parameters and weekly session protocols in these studies greatly varied. Most included relatively small samples (14-60 patients) with a short follow-up (12 weeks). In comparative studies of the use of PTNS with placebo, a reduction of more than 50\% of the urgency and urge-incontinence symptoms in 54-71\% of patients receiving against 0-22\% of patients in the control group (117-119). Most studies showed improvement of quality of life as evaluated by different questionnaires (118-120). Systematic reviews demonstrated that $37-100 \%$ of patients treated with PTNS experienced treatment success, with different evaluation criteria having been adopted and minimum adverse effects (121123). A recent meta-analysis indicated a seven-fold higher chance of clinical improvement in the PTNS treated group versus control group.

Studies evaluating the duration of PTNS effects without further treatments showed, after completion of the initial protocol, maintenance of efficacy for up to six months $(124,125)$. Studies with up to three-year follow-ups demonstrated sustained efficacy upon a monthly treatment, after one cycle for 12 weeks $(117,126)$. Maintenance protocols are variable and tend to be individualized. Typically, after the 12 weeks of initial treat- ment, the interval between sessions is progressively increase until it reaches one session a month $(118,126)$. Patients experiencing recurrence with this maintenance protocol are adjusted and receive reapplications within shorter intervals. In the SUmiT study, $41 \%$ of patients required less than one session a month, 55\% needed 1-2 monthly sessions, and 4\% more than two sessions a month. The most commonly seen adverse effects of the treatment with PTNS include pain at the puncture site (medial malleolus), local bleeding, paresthesia, and excoriations. These effects are rare and affect about $5 \%$ of patients $(118,120)$. It is important to stress the high rate of abandon at the long term follow-up, which reaches as much as 42\% (118).

\section{Botulinum toxin}

The botulinum toxin type A counting with the largest number of scientific studies and that is approved for the treatment of overactive bladder by the Food and Drug Administration (FDA) and European Medicines Agency (EMA) is the one called onabotulinumtoxinA. Other botulinum toxins, such as abobotulinumtoxinA and incobotulinumtoxinA, were less frequently studied for bladder indication. Their efficacy and safety are not well known. In addition, their use is not provided in label for this indication. For this reason, our text will be based on the data published on onabotulinumtoxinA.

The treatment with onabotulinumtoxinA can be used to patients that are refractory to the conservative treatment, after detailed education. Patients must be able to attend frequent follow-up visits in order to evaluate the bladder emptying pattern. They must accept the possibility of intermittent bladder catheterization, if necessary.

The efficacy and side effects of the treatment with onabotulinumtoxinA depend on the dose used. The recommended dose for most patients should be 100 or $150 \mathrm{U}$. The use of $150 \mathrm{U}$ results in a discrete improvement of efficacy, but higher risk of urinary retention (127-130).

Most studies evaluated the bolutinum toxin injection into the body of the bladder, sparing the bladder trigone (127-131). Different protocols were used, including injections into 10-20 bladder sites and dilution in such a way to inject 0.5-1.0 $\mathrm{mL}$ per site. OnabotulinumtoxinA injection should 
be performed deeply into the detrusor. Submucosal injection was less often evaluated and its results are not well known.

OnabotulinumtoxinA injection can be performed with local anesthesia, sedation, spinal blo$\mathrm{ck}$, or general anesthesia. The procedure with local anesthesia usually requires the use of flexible cystoscope and a longer injection needle, at a higher cost. With other forms of anesthesia, the procedure can be performed with the aid of rigid cystoscope and a shorter injection needle. This equipment is cheaper and easily available. The choice of the type of anesthesia should be agreed upon by both physician and patient, considering the equipment availability.

OnabotulinumtoxinA at a dose of 100 or $150 \mathrm{U}$ results in improvement of several clinical parameters and the quality of life. The impact of the treatment on these parameters depends on the severity of symptoms before treatment, the dose used, and the evaluation time point after the procedure. In comparative studies of onabotulinumtoxinA with placebo, a reduction of more than $50 \%$ of urgency and urge-incontinence symptoms was observed in 57-68\% of patients receiving 100 U versus $27-30 \%$ of those receiving placebo. Total continence was observed in 23-55\% of patients receiving $100 \mathrm{U}$ versus $6-11 \%$ of those receiving placebo (129-131). The improvement of the quality of life, as evaluated through different questionnaires, was 60-63\% among patients receiving $100 \mathrm{U}$ versus $27-29 \%$ of patients receiving placebo $(130,131)$. The urodynamic efficacy of the treatment with onabotulinumtoxinA has been little studied. Some studies showed improvement of the cystometric bladder capacity (25\%) and absence of the detrusor overactivity (35-39\%) (132-134).

The most commonly seen adverse effects following onabotulinumtoxinA injection include urinary tract infections, increase of the post-void residual volume, and urinary retention requiring bladder catheterization (127, 129-131). Urinary tract infections occurred in $15-55 \%$ of patients receiving $100 \mathrm{U}$ versus 6-28\% of those receiving placebo. Post-void residue superior to $150 \mathrm{~mL}$ was observed in 7-26\% of patients receiving $100 \mathrm{U}$ versus up to $1 \%$ of those receiving placebo (127131). Urinary retention requiring bladder cathete- rization was observed in 3-18\% of patients receiving $100 \mathrm{U}$ versus $0-2 \%$ of those receiving placebo (127-131, 134). The urinary retention may last a few days to several weeks, and in less than 50\% of patients it lasts more than six weeks $(128,130)$. Other side effects include hematuria (4-18\%) and muscular weakness (3-9\%).

The majority of studies evaluated patients during three months, and some studies evaluated patients for 6-12 months, with sustained efficacy throughout this period (127-131, 134, 135).

Some factors are associated with a higher chance of complications, particularly urinary retention requiring bladder catheterization. Among these factors, being male, over 75 years old, and initial post-void residue superior to $100 \mathrm{~mL}$ (132).

Most of the studies evaluating reinjections are retrospective and without a control group. The interval between injections varied from 6 to 14 months (136-139), with most of them showing maintenance of the treatment effects after reinjections $(136,137,140)$.

Treatment discontinuation is dependent on factors such as follow-up time, treatment efficacy and side effects, particularly urinary retention and urinary tract infections. In a study following up patients for 60 months, the treatment discontinuation rate was 64\% mainly due to the emergence of complications such as urinary retention and urinary tract infections and for the lack of efficacy of the initial injection (138).

The treatment with onabotulinumtoxinA may improve patients with moderate-to-severe symptoms of overactive bladder that did not respond to the conservative treatment. The dose of $100 \mathrm{U}$ results in a lower rate of side effects. The benefits of the treatment with onabotulinumtoxinA at a dose of $100 \mathrm{U}$ outweigh the risks and discomforts in patients with refractory overactive bladder to the conservative treatment. It is critical that patients that are candidates for this treatment are carefully educated about the risks and they should accept the possibility that they need bladder catheterization for relief. Patients should also be informed that the effects of the treatment diminish over time and the vast majority will need reinjections. The current evidence limitations include short follow-up time in better designed stu- 
dies and variations of protocol injections and adverse effect reporting.

\section{Sacral neuromodulation}

Treatment with sacral neuromodulation (SNM) can be offered to patients with overactive bladder symptoms that are refractory to the conservative treatment after detailed education.

Studies evaluating this therapeutic modality are based on the use of the equipment Interstim (Medtronic, Minneapolis, USA), which has gone through changes in the last years, with the incorporation of a minimally invasive surgical technique, lower volume battery, anchored electrodes, and the introduction of the percutaneous stimulation testing (percutaneous nerve evaluation - PNE).

The treatment with SNM involves a test phase (first phase), which may be performed with the implantation of a temporary electrode (PNE) or the implantation of the permanent electrode. The implantation of the electrode for PNE is simpler and less expensive; however, the results are inferior to those achieved with the permanent electrode. Studies reported as high success rates during the test phase with PNE as 44-60\% (141-144) and 69$81 \%$ with the implantation of the permanent electrode $(141,142,145,146)$. Around $44 \%$ of patients failing the PNE test have positive response when undergoing a new test with the implantation of the permanent electrode (142).

The second phase of the treatment is indicated in cases showing good clinical response to the test phase. In general, a 50\% or more improvement of urgency urinary incontinence symptoms is the parameter used as the success criterion. This treatment phase consists of the implantation of the generator in cases where the permanent electrode was implanted during the test phase. In cases where the first phase was performed with PNE, the second phase consists of the implantation of the entire system, including the permanent electrode and the generator.

Most of the studies evaluating this treatment modality consist of observational series without a control group. Some studies report long-term results (up to five years). Overall, studies show significant improvement of several clinical and quality-of-life parameters.
Improvement of more than 50\% of urgency and incontinence symptoms is observed in $65-87 \%$ of patients in the short-term follow-up (up to six months) (147). Most of the patients have good results in the long run. Improvement of more than 50\% of urgency and urgency incontinence symptoms is observed in $62-70 \%$ of patients after a five-year follow-up (147-151). The satisfaction rates of patients followed up for more than five years is as high as $60-80 \%$ (152). The healing of urgency urinary incontinence is observed in 20-55\% of patients $(151,153)$.

Treatment results may be long-lasting, although the adverse effect and additional surgery rates are significant. However, the potential variability of the rates observed in old studies as well as in more recent ones incorporating technological advances should be taken into account. The most commonly reported adverse effects include local pain at the generator implantation site (3-20\%), pain at the electrode site (4-19\%), electrode migration (1-9\%), infection (2-14\%), shock sensation (5-8\%), and need for revision surgery (6-39\%). In most studies, the revision surgery rates were superior to $30 \%$. There is evidence that the current procedures, with less invasive surgical technique and the use of anchored electrodes, result in lower adverse effect rates $(147-151,154,155)$. In a study evaluating patients from Medicare undergoing treatment with SNM in the period from 1997 to 2007, the generator removal rate was about $11 \%$ in a 60-month follow-up on average (156).

Patients should be informed about the need for periodic replacement of the generator, with the interval depending on the stimulation parameters used. Patients should be able to handle the remote control in order to optimize the device functioning. Patients must accept the fact that magnetic resonance imaging is contraindicated for individuals using the device (except for cranial magnetic resonance imaging, provided that the manufacturer's instructions are followed). By taking into consideration the negative effects of the overactive bladder symptoms on patients' quality of life, it is possible to state that the benefits from SNM outweigh the risks and discomforts of the treatment in selected, carefully educated patients. 
Recommendation of this treatment is limited due to the fact that the majority of studies have an observational design, small samples, different studies reporting results in the same group of patients, and the lack of information on the protocols used by patients in order to maintain the treatment results in the long term.

\section{Surgical treatment of overactive bladder}

In rare occasions, bladder augmentation or urinary diversion may be considered in highly selected patients with refractory overactive bladder. Almost all papers reporting results from bladder augmentation are based on populations with neurogenic bladder dysfunctions. Very little is known about its use in patients with idiopathic overactive bladder. The risks of the procedure are high and many patients may need intermittent catheterization for bladder emptying.

\section{CONFLICT OF INTEREST}

Speaker Allergan, Advisory board Astellas.

\section{REFERENCES}

1. Jayarajan J, Radomski SB. Pharmacotherapy of overactive bladder in adults: a review of efficacy, tolerability, and quality of life. Res Rep Urol. 2013;6:1-16.

2. Staskin DR. Overactive bladder in the elderly: a guide to pharmacological management. Drugs Aging. 2005;22:1013-28.

3. Bhidayasiri R, Cardoso F, Truong DD. Botulinum toxin in blepharospasm and oromandibular dystonia: comparing different botulinum toxin preparations. Eur $\mathrm{J}$ Neurol. 2006;13:21-9.

4. Abrams P, Andersson KE, Buccafusco JJ, Chapple C, de Groat $W C$, Fryer $A D$, et al. Muscarinic receptors: their distribution and function in body systems, and the implications for treating overactive bladder. Br J Pharmacol. 2006;148:565-78.

5. Roxburgh C, Cook J, Dublin N. Anticholinergic drugs versus other medications for overactive bladder syndrome in adults. Cochrane Database Syst Rev. 2007:4:CD003190.

6. Hegde SS. Muscarinic receptors in the bladder: from basic research to therapeutics. Br J Pharmacol. 2006;147:S80-7.

7. Wagg A: The cognitive burden of anticholinergics in the elderly - implications for the treatment of overactive bladder. Eur Urol Rev. 2012;7:42-9.
8. Chancellor MB, Levanovich P, Rajaganapathy BR. et al: Optimum management of overactive bladder: medication vs BotoxTM vs InterStimTM vs UrgentTM PC. Urol Pract 2014;1:7-12.

9. Gormley EA, Lightner DJ, Burgio KL, Chai TC, Clemens $J Q$, Culkin DJ, et al. Diagnosis and treatment of overactive bladder (non-neurogenic) in adults: AUA/SUFU guideline. J Urol. 2012;188:2455-63.

10. Hood B, Andersson KE. Common theme for drugs effective in overactive bladder treatment: inhibition of afferent signaling from the bladder. Int J Urol. 2013;20:21-7.

11. Roxburgh C, Cook J, Dublin N. Anticholinergic drugs versus other medications for overactive bladder syndrome in adults. Cochrane Database Syst Rev. 2007;3:CD003190. Update in: Cochrane Database Syst Rev. 2007;4:CD003190.

12. Saks EK, Arya LA. Pharmacologic management of urinary incontinence, voiding dysfunction, and overactive bladder. Obstet Gynecol Clin North Am. 2009;36:493-507. Erratum in: Obstet Gynecol Clin North Am. 2010;37:135.

13. Kelleher CJ, Cardozo LD, Khullar V, Salvatore S. A mediumterm analysis of the subjective efficacy of treatment for women with detrusor instability and low bladder compliance. Br J Obstet Gynaecol. 1997;104:988-93.

14. Benner JS, Nichol MB, Rovner ES, Jumadilova Z, Alvir J, Hussein $M$, et al. Patient-reported reasons for discontinuing overactive bladder medication. BJU Int. 2010;105:1276-82.

15. Chapple CR, Kaplan SA, Mitcheson D, Klecka J, Cummings J, Drogendijk T, et al. Randomized double-blind, activecontrolled phase 3 study to assess 12-month safety and efficacy of mirabegron, a $\beta(3)$-adrenoceptor agonist, in overactive bladder. Eur Urol. 2013;63:296-305.

16. Goode PS, Burgio KL, Locher JL, Umlauf MG, Lloyd LK, Roth DL. Urodynamic changes associated with behavioral and drug treatment of urge incontinence in older women. J Am Geriatr Soc. 2002;50:808-16.

17. Arruda RM, Castro RA, Sousa GC, Sartori MG, Baracat EC, Girão MJ. Prospective randomized comparison of oxybutynin, functional electrostimulation, and pelvic floor training for treatment of detrusor overactivity in women. Int Urogynecol J Pelvic Floor Dysfunct. 2008;19:1055-61.

18. Colombo M, Zanetta G, Scalambrino S, Milani R. Oxybutynin and bladder training in the management of female urinary urge incontinence: a randomized study. Int Urogynecol J Pelvic Floor Dysfunct. 1995;6:63-7.

19. Burgio KL, Locher JL, Goode PS, Hardin JM, McDowell BJ, Dombrowski M, et al. Behavioral vs drug treatment for urge urinary incontinence in older women: a randomized controlled trial. JAMA. 1998;280:1995-2000.

20. Song C, Park JT, Heo KO, Lee KS, Choo MS. Effects of bladder training and/or tolterodine in female patients with overactive bladder syndrome: a prospective, randomized study. J Korean Med Sci. 2006;21:1060-3. 
21. Abrams P, Freeman R, Anderström C, Mattiasson A. Tolterodine, a new antimuscarinic agent: as effective but better tolerated than oxybutynin in patients with an overactive bladder. Br J Urol. 1998;81:801-10.

22. Abrams P, Cardozo L, Chapple C, Serdarevic D, Hargreaves K, Khullar V, et al. Comparison of the efficacy, safety, and tolerability of propiverine and oxybutynin for the treatment of overactive bladder syndrome. Int J Urol. 2006;13:692-8.

23. Anderson RU, Mobley D, Blank B, Saltzstein D, Susset J, Brown JS. Once daily controlled versus immediate release oxybutynin chloride for urge urinary incontinence. OROS Oxybutynin Study Group. J Urol. 1999;161:1809-12.

24. Appell RA, Sand P, Dmochowski R, Anderson R, Zinner $\mathrm{N}$, Lama $\mathrm{D}$, et al. Prospective randomized controlled trial of extended-release oxybutynin chloride and tolterodine tartrate in the treatment of overactive bladder: results of the OBJECT Study. Mayo Clin Proc. 2001;76:358-63.

25. Barkin J, Corcos J, Radomski S, Jammal MP, Miceli PC, Reiz JL, et al. A randomized, double-blind, parallelgroup comparison of controlled- and immediate-release oxybutynin chloride in urge urinary incontinence. Clin Ther. 2004;26:1026-36.

26. Burgio KL, Goode PS, Richter HE, Markland AD, Johnson TM 2nd, Redden DT. Combined behavioral and individualized drug therapy versus individualized drug therapy alone for urge urinary incontinence in women. J Urol. 2010;184:598603.

27. Cardozo L, Lisec M, Millard R, van Vierssen Trip 0, Kuzmin I, Drogendijk TE, et al. Randomized, double-blind placebo controlled trial of the once daily antimuscarinic agent solifenacin succinate in patients with overactive bladder. J Urol. 2004;172:1919-24.

28. Chancellor M, Freedman S, Mitcheson H, Antoci J, Primus G, Wein A. Tolterodine, an effective and well tolerated treatment for urge incontinence and other overactive bladder symptoms. Clin Drug Investig. 2000;19:83-91.

29. Chapple CR, Rechberger T, Al-Shukri S, Meffan P, Everaert $\mathrm{K}$, Huang $\mathrm{M}$, et al. Randomized, double-blind placebo-and tolterodine-controlled trial of the once-daily antimuscarinic agent solifenacin in patients with symptomatic overactive bladder. BJU Int. 2004;93:303-10.

30. Chapple CR, Araño P, Bosch JL, De Ridder D, Kramer AE, Ridder AM. Solifenacin appears effective and well tolerated in patients with symptomatic idiopathic detrusor overactivity in a placebo- and tolterodine-controlled phase 2 dosefinding study. BJU Int. 2004;93:71-7. Erratum in: BJU Int. 2004;93:1135.

31. Chapple C, DuBeau C, Ebinger U, Rekeda L, Viegas A. Darifenacin treatment of patients $>$ or $=65$ years with overactive bladder: results of a randomized, controlled, 12week trial. Curr Med Res Opin. 2007;23:2347-58.
32. Chapple C, Van Kerrebroeck P, Tubaro A, Haag-Molkenteller C, Forst HT, Massow U, et al. Clinical efficacy, safety, and tolerability of once-daily fesoterodine in subjects with overactive bladder. Eur Urol. 2007;52:1204-12. Erratum in: Eur Urol. 2008;53:1319.

33. Davila GW, Daugherty CA, Sanders SW; Transdermal Oxybutynin Study Group. A short-term, multicenter, randomized doubleblind dose titration study of the efficacy and anticholinergic side effects of transdermal compared to immediate release oral oxybutynin treatment of patients with urge urinary incontinence. J Urol. 2001;166:140-5.

34. Diokno AC, Appell RA, Sand PK, Dmochowski RR, Gburek BM, Klimberg IWetal. Prospective, randomized, double-blind study of the efficacy and tolerability of the extended-release formulations of oxybutynin and tolterodine for overactive bladder: results of the OPERA trial. Mayo Clin Proc. 2003;78:687-95.

35. Dmochowski RR, Sand PK, Zinner NR, Gittelman MC, Davila GW, Sanders SW; Transdermal Oxybutynin Study Group. Comparative efficacy and safety of transdermal oxybutynin and oral tolterodine versus placebo in previously treated patients with urge and mixed urinary incontinence. Urology. 2003;62:237-42.

36. Dmochowski RR, Sand PK, Zinner NR, Staskin DR. Trospium $60 \mathrm{mg}$ once daily (QD) for overactive bladder syndrome: results from a placebo-controlled interventional study. Urology. 2008;71:449-54.

37. Drutz HP, Appell RA, Gleason D, Klimberg I, Radomski S. Clinical efficacy and safety of tolterodine compared to oxybutynin and placebo in patients with overactive bladder. Int Urogynecol J Pelvic Floor Dysfunct. 1999;10:283-9.

38. Frenkl TL, Zhu H, Reiss T, Seltzer O, Rosenberg E, Green S. A multicenter, double-blind, randomized, placebo controlled trial of a neurokinin-1 receptor antagonist for overactive bladder. J Urol. 2010;184:616-22.

39. Giannitsas K, Perimenis P, Athanasopoulos A, Gyftopoulos K, Nikiforidis G, Barbalias G. Comparison of the efficacy of tolterodine and oxybutynin in different urodynamic severity grades of idiopathic detrusor overactivity. Eur Urol. 2004;46:776-82; discussion 782-3.

40. Haab F, Stewart L, Dwyer P. Darifenacin, an M3 selective receptor antagonist, is an effective and well-tolerated oncedaily treatment for overactive bladder. Eur Urol. 2004;45:420-9; discussion 429.

41. Halaska M, Ralph G, Wiedemann A, Primus G, Ballering-Brühl B, Höfner K, et al. Controlled, double-blind, multicentre clinical trial to investigate long-term tolerability and efficacy of trospium chloride in patients with detrusor instability. World $\mathrm{J}$ Urol. 2003;20:392-9.

42. Herschorn S, Swift S, Guan Z, Carlsson M, Morrow JD, Brodsky $\mathrm{M}$, et a I. Comparison of fesoterodine and tolterodine extended release for the treatment of overactive bladder: a head-to-head placebo-controlled trial. BJU Int. 2010;105:58-66. 
43. Herschorn S, Stothers L, Carlson K, Egerdie B, Gajewski JB, Pommerville $\mathrm{P}$, et al. Tolerability of $5 \mathrm{mg}$ solifenacin once daily versus $5 \mathrm{mg}$ oxybutynin immediate release 3 times daily: results of the VECTOR trial. J Urol. 2010;183:1892-8.

44. Hill S, Khullar V, Wyndaele JJ, Lheritier K; Darifenacin Study Group. Dose response with darifenacin, a novel once-daily M3 selective receptor antagonista for the treatment of overactive bladder: results of a fixed dose study. Int Urogynecol J Pelvic Floor Dysfunct. 2006;17:239-47.

45. Homma Y, Paick JS, Lee JG, Kawabe K; Japanese and Korean Tolterodine Study Group. Clinical efficacy and tolerability of extended-release tolterodine and immediate-release oxybutynin in Japanese and Korean patients with an overactive bladder: a randomized, placebo-controlled trial. BJU Int. 2003;92:741-7. Erratum in: BJU Int. 2004:93:1135.

46. Homma Y, Koyama N. Minimal clinically important change in urinary incontinence detected by a quality of life assessment tool in overactive bladder syndrome with urge incontinence. Neurourol Urodyn. 2006;25:228-35.

47. Jacquetin B, Wyndaele J. Tolterodine reduces the number of urge incontinence episodes in patients with an overactive bladder. Eur J Obstet Gynecol Reprod Biol. 2001;98:97-102.

48. Jonas U, Höfner K, Madersbacher H, Holmdahl TH. Efficacy and safety of two doses of tolterodine versus placebo in patients with detrusor overactivity and symptoms of frequency, urge incontinence, and urgency: urodynamic evaluation. The International Study Group. World J Urol. 1997;15:144-51. Erratum in: World J Urol 1997;15:210.

49. Karram MM, Toglia MR, Serels SR, Andoh M, Fakhoury A, Forero-Schwanhaeuser S. Treatment with solifenacin increases warning time and improves symptoms of overactive bladder: results from VENUS, a randomized, double-blind, placebocontrolled trial. Urology. 2009;73:14-8.

50. Lackner TE, Wyman JF, McCarthy TC, Monigold M, Davey C. Randomized, placebo-controlled trial of the cognitive effect, safety, and tolerability of oral extended-release oxybutynin in cognitively impaired nursing home residentes with urge urinary incontinence. J Am Geriatr Soc. 2008;56:862-70.

51. Lee JG, Hong JY, Choo MS, Kwon HY, Chung DY, Lee KS, et al. Tolterodine: as effective but better tolerated than oxybutynin in Asian patients with symptoms of overactive bladder. Int J Urol. 2002;9:247-52.

52. Leung HY, Yip SK, Cheon C, Liu YS, Lau J, Wong HK, et al. A randomized controlled trial of tolterodine and oxybutynin on tolerability and clinical efficacy for treating Chinese women with an overactive bladder. BJU Int. 2002;90:375-80.

53. Malone-Lee JG, Walsh JB, Maugourd MF. Tolterodine: a safe and effective treatment for older patients with overactive bladder. J Am Geriatr Soc. 2001;49:700-5.

54. Malone-Lee JG, Al-Buheissi S. Does urodynamic verification of overactive bladder determine treatment success? Results from a randomized placebo-controlled study. BJU Int. 2009;103:931-7.
55. Malone-Lee J, Shaffu B, Anand C, Powell C. Tolterodine: superior tolerability than and comparable efficacy to oxybutynin in individuals 50 years old or older with overactive bladder: a randomized controlled trial. J Urol. 2001;165:1452-6.

56. Millard R, Tuttle J, Moore K, Susset J, Clarke B, Dwyer $P$, et al. Clinical efficacy and safety of tolterodine compared to placebo in detrusor overactivity. J Urol. 1999;161:1551-5.

57. Nelken RS, Ozel BZ, Leegant AR, Felix JC, Mishell DR Jr. Randomized trial of estradiol vaginal ring versus oral oxybutynin for the treatment of overactive bladder. Menopause. 2011;18:962-6.

58. Nitti VW, Rovner ES, Bavendam T. Response to fesoterodine in patients with an overactive bladder and urgency urinary incontinence is independent of the urodynamic finding of detrusor overactivity. BJU Int. 2010;105:1268-75.

59. Ozdedeli S, Karapolat H, Akkoc Y. Comparison of intravaginal electrical stimulation and trospium hydrochloride in women with overactive bladder syndrome: a randomized controlled study. Clin Rehabil. 2010;24:342-51.

60. Peters KM, Macdiarmid SA, Wooldridge LS, Leong FC, Shobeiri SA, Rovner ES, et al. Randomized trial of percutaneous tibial nerve stimulation versus extendedrelease tolterodine: results from the overactive bladder innovative therapy trial. J Urol. 2009;182:1055-61.

61. Rackley R, Weiss JP, Rovner ES, Wang JT, Guan Z; 037 STUDY GROUP. Nighttime dosing with tolterodine reduces overactive bladder-related nocturnal micturitions in patients with overactive bladder and nocturia. Urology. 2006;67:731-6.

62. Rentzhog L, Stanton SL, Cardozo L, Nelson E, Fall M, Abrams P. Efficacy and safety of tolterodine in patients with detrusor instability: a dose-ranging study. $\mathrm{Br} J$ Urol. 1998;81:42-8.

63. Robinson D, Cardozo L, Terpstra G, Bolodeoku J; Tamsulosin Study Group. A randomized double-blind placebo-controlled multicentre study to explore the efficacy and safety of tamsulosin and tolterodine in women with overactive bladder syndrome. BJU Int. 2007;100:840-5.

64. Rogers R, Bachmann G, Jumadilova Z, Sun F, Morrow JD, Guan Z, et al. Efficacy of tolterodine on overactive bladder symptoms and sexual and emotional quality of life in sexually active women. Int Urogynecol J Pelvic Floor Dysfunct. 2008;19:1551-7.

65. Rudy D, Cline K, Harris R, Goldberg K, Dmochowski R. Multicenter phase III trial studying trospium chloride in patients with overactive bladder. Urology. 2006;67:275-80.

66. Sancaktar M, Ceyhan ST, Akyol I, Muhcu M, Alanbay I, Mutlu Ercan C, et al. The outcome of adding peripheral neuromodulation (Stoller afferent neuro-stimulation) to anti-muscarinic therapy in women with severe overactive bladder. Gynecol Endocrinol. 2010;26:729-32. 
67. Sand PK, Miklos J, Ritter H, Appell R. A comparison of extended-release oxybutynin and tolterodine for treatment of overactive bladder in women. Int Urogynecol J Pelvic Floor Dysfunct. 2004;15:243-8.

68. Staskin D, Sand P, Zinner N, Dmochowski R; Trospium Study Group. Once daily trospium chloride is effective and well tolerated for the treatment of overactive bladder: results from a multicenter phase III trial. J Urol. 2007;178:978-83; discussion 983-4.

69. Steers W, Corcos J, Foote J, Kralidis G. An investigation of dose titration with darifenacin, an M3-selective receptor antagonist. BJU Int. 2005;95:580-6. Erratum in: BJU Int. 2005;95:1385-6.

70. Sussman D, Garely A. Treatment of overactive bladder with once-daily extended-release tolterodine or oxybutynin: the antimuscarinic clinical effectiveness trial (ACET). Curr Med Res Opin. 2002;18:177-84.

71. Tseng LH, Wang AC, Chang YL, Soong YK, Lloyd LK, Ko YJ. Randomized comparison of tolterodine with vaginal estrogen cream versus tolterodine alone for the treatment of postmenopausal women with overactive bladder syndrome. Neurourol Urodyn. 2009;28:47-51.

72. Vardy MD, Mitcheson HD, Samuels TA, Wegenke JD, ForeroSchwanhaeuser S, Marshall TS, He W. Effects of solifenacin on overactive bladder symptoms, symptom bother and other patient-reported outcomes: results from VIBRANT - a double-blind, placebo-controlled trial. Int J Clin Pract. 2009;63:1702-14.

73. Versi E, Appell R, Mobley D, Patton W, Saltzstein D. Dry mouth with conventional and controlled-release oxybutynin in urinary incontinence. The Ditropan XL Study Group. Obstet Gynecol. 2000;95:718-21.

74. Wang AC, Chih SY, Chen MC. Comparison of electric stimulation and oxybutynin chloride in management of overactive bladder with special reference to urinary urgency: a randomized placebo-controlled trial. Urology. 2006:68:999-1004.

75. Yamaguchi O, Marui E, Kakizaki H, Itoh N, Yokota T, Okada $\mathrm{H}$, et al. Japanese Solifenacin Study Group. Randomized, double-blind, placebo- and propiverine-controlled trial of the once-daily antimuscarinic agent solifenacin in Japanese patients with overactive bladder. BJU Int. 2007;100:579-87.

76. Vella M, Cardozo L. Review of fesoterodine. Expert Opin Drug Saf. 2011;10:805-8.

77. Zát'ura F, Vsetica J, Abadías M, Pavlík I, Schraml P, Brod'ák $M$, et al. Cizolirtine citrate is safe and effective for treating urinary incontinence secondary to overactive bladder: a phase 2 proof-of-concept study. Eur Urol. 2010;57:145-52.

78. Zinner NR, Mattiasson A, Stanton SL. Efficacy, safety, and tolerability of extended-release once-daily tolterodine treatment for overactive bladder in older versus younger patients. J Am Geriatr Soc. 2002;50:799-807.
79. Zinner N, Gittelman M, Harris R, Susset J, Kanelos A, Auerbach S; et al. Trospium chloride improves overactive bladder symptoms: a multicenter phase III trial. J Urol. 2004;171:2311-5.

80. Zinner N, Tuttle J, Marks L. Efficacy and tolerability of darifenacin, a muscarinic M3 selective receptor antagonist (M3 SRA), compared with oxybutynin in the treatment of patients with overactive bladder. World J Urol. 2005;23:248-52.

81. Zinner N, Susset J, Gittelman M, Arguinzoniz M, Rekeda L, Haab F. Efficacy, tolerability and safety of darifenacin, an M(3) selective receptor antagonist: na investigation of warning time in patients with OAB. Int J Clin Pract. 2006;60:119-26. Erratum in: Int J Clin Pract. 2006;60:890.

82. Chapple C, Khullar V, Gabriel Z, Dooley JA. The effects of antimuscarinic treatments in overactive bladder: a systematic review and meta-analysis. Eur Urol. 2005;48:5-26. Erratum in: Eur Urol. 2005;48:875.

83. Chapple CR, Khullar V, Gabriel Z, Muston D, Bitoun CE, Weinstein $D$. The effects of antimuscarinic treatments in overactive bladder: an update of a systematic review and meta-analysis. Eur Urol. 2008;54:543-62.

84. Khullar V, Chapple C, Gabriel Z, Dooley JA. The effects of antimuscarinics on health-related quality of life in overactive bladder: a systematic review and meta-analysis. Urology. 2006:68:38-48

85. Novara G, Galfano A, Secco S, D'Elia C, Cavalleri S, Ficarra V et al. A systematic review and meta-analysis of randomized controlled trials with antimuscarinic drugs for overactive bladder. Eur Urol. 2008;54:740-63.

86. Anderson RU, MacDiarmid S, Kell S, Barada JH, Serels S, Goldberg RP. Effectiveness and tolerability of extended-release oxybutynin versus extended-release tolterodine in women with or without prior anticholinergic treatment for overactive bladder. Int Urogynecol J Pelvic Floor Dysfunct. 2006;17:502-11.

87. Pagoria D, O'Connor RC, Guralnick ML. Antimuscarinic drugs: review of the cognitive impact when used to treat overactive bladder in elderly patients. Curr Urol Rep. 2011:12:351-7.

88. Madhuvrata P, Cody JD, Ellis G, Herbison GP, Hay-Smith EJ. Which anticholinergic drug for overactive bladder symptoms in adults. Cochrane Database Syst Rev. 2012;1:CD005429.

89. Kay G, Crook T, Rekeda L, Lima R, Ebinger U, Arguinzoniz $M$, et al. Differential effects of the antimuscarinic agents darifenacin and oxybutynin ER on memory in older subjects. Eur Urol. 2006;50:317-26.

90. Fader M, Glickman S, Haggar V, Barton R, Brooks R, MaloneLee J. Intravesical atropine compared to oral oxybutynin for neurogenic detrusor overactivity: a double-blind, randomized crossover trial. J Urol. 2007;177:208-13;discussion 213.

91. Gajewski JB, Awad SA. Oxybutynin versus propantheline in patients with multiple sclerosis and detrusor hyperreflexia. $J$ Urol. 1986;135:966-8. 
92. Madersbacher $H$, Stöhrer M, Richter R, Burgdörfer $H$, Hachen HJ, Mürtz G. Trospium chloride versus oxybutynin: a randomized, double-blind, multicentre trial in the treatment of detrusor hyper-reflexia. Br J Urol. 1995;75:452-6.

93. Stöhrer M, Mürtz G, Kramer G, Schnabel F, Arnold EP, Wyndaele JJ; et al. Propiverine compared to oxybutynin in neurogenic detrusor overactivity--results of a randomized, double-blind, multicenter clinical study. Eur Urol. 2007;51:235-42.

94. Wagg A, Dale M, Tretter R, Stow B, Compion G. Randomised, multicentre, placebo-controlled, double-blind crossover study investigating the effect of solifenacin and oxybutynin in elderly people with mild cognitive impairment: the SENIOR study. Eur Urol. 2013;64:74-81.

95. Oefelein MG. Safety and tolerability profiles of anticholinergic agents used for the treatment of overactive bladder. Drug Saf. 2011;34:733-54.

96. Chancellor MB, Staskin DR, Kay GG, Sandage BW, Oefelein $M G$, Tsao JW. Blood-brain barrier permeation and efflux exclusion of anticholinergics used in the treatment of overactive bladder. Drugs Aging. 2012;29:259-73.

97. Kay GG, Staskin DR, MacDiarmid S, Mcllwain M, Dahl NV. Cognitive effects of oxybutynin chloride topical gel in older healthy subjects: a 1-week, randomized, double-blind, placebo- and active-controlled study. Clin Drug Investig. 2012;32:707-14.

98. Kessler TM, Bachmann LM, Minder C, Löhrer D, Umbehr $\mathrm{M}$, Schünemann $\mathrm{HJ}$, et al. Adverse event assessment of antimuscarinics for treating overactive bladder: a network meta-analytic approach. PLoS One. 2011;6:e16718.

99. Geoffrion R; Society of Obstetricians and Gynaecologists of Canada. Treatments for overactive bladder: focus on pharmacotherapy. J Obstet Gynaecol Can. 2012;34:1092-101.

100. Nitti VW, Rosenberg S, Mitcheson DH, He W, Fakhoury A, Martin NE. Urodynamics and safety of the $\beta_{3}$-adrenoceptor agonist mirabegron in males with lower urinary tract symptoms and bladder outlet obstruction. J Urol. 2013;190:1320-7.

101. Lee RT, Bamberger M, Ellsworth P. Impact of mirabegron extended-release on the treatment of overactive bladder with urge urinary incontinence, urgency, and frequency. Res Rep Urol. 2013;5:147-57.

102. Chapple CR. $\beta_{3}$-agonist therapy: a new advance in the management of overactive bladder? Eur Urol. 2012;62:841-2.

103. Igawa Y, Michel MC. Pharmacological profile of $\beta 3$ adrenoceptor agonists in clinical development for the treatment of overactive bladder syndrome. Naunyn Schmiedebergs Arch Pharmacol. 2013;386:177-83.

104. Kanie S, Otsuka A, Yoshikawa S, Morimoto T, Hareyama N, Okazaki S, et al. Pharmacological effect of TRK-380, a novel selective human $\beta 3$-adrenoceptor agonist, on mammalian detrusor strips. Urology. 2012;79:744.e1-7.
105. Birder LA, Nealen ML, Kiss S, de Groat WC, Caterina MJ Wang $E$, et al. Beta-adrenoceptor agonists stimulate endothelial nitric oxide synthase in rat urinary bladder urothelial cells. J Neurosci. 2002;22:8063-70.

106. Murakami S, Chapple CR, Akino H, Sellers DJ, ChessWilliams $R$. The role of the urothelium in mediating bladder responses to isoprenaline. BJU Int. 2007;99:669-73.

107. Herschorn S, Barkin J, Castro-Diaz D, Frankel JM, EspunaPons $M$, Gousse $A E$, et al. A phase III, randomized, doubleblind, parallel-group, placebo-controlled, multicentre study to assess the efficacy and safety of the $\beta 3$ adrenoceptor agonist mirabegron, in patients with symptoms of overactive bladder. Urology. 2013;82:313-20. Erratum in: Urology. 2013;82:1457.

108. Yamaguchi 0, Marui E, Kakizaki H, Homma Y, Igawa Y, Takeda M, et al. Phase III, randomised, double-blind, placebo-controlled study of the $\beta 3$-adrenoceptor agonist mirabegron, $50 \mathrm{mg}$ once daily, in Japanese patients with overactive bladder. BJU Int. 2014;113:951-60.

109. Chapple CR, Dvorak V, Radziszewski P, Van Kerrebroeck $P$, Wyndaele JJ, Bosman B, et al. A phase II dose-ranging study of mirabegron in patients with overactive bladder. Int Urogynecol J. 2013;24:1447-58.

110. Khullar V, Amarenco G, Angulo JC, Cambronero J, Høye $\mathrm{K}$, Milsom I, et al. Efficacy and tolerability of mirabegron, a $\beta(3)$-adrenoceptor agonist, in patients with overactive bladder: results from a randomised European-Australian phase 3 trial. Eur Urol. 2013;63:283-95.

111. Chapple CR, Amarenco G, López Aramburu MA, Everaert $\mathrm{K}$, Liehne J, Lucas $\mathrm{M}$, et al. A proof-of-concept study: mirabegron, a new therapy for overactive bladder. Neurourol Urodyn. 2013;32:1116-22.

112. Nitti VW, Auerbach S, Martin N, Calhoun A, Lee M, Herschorn S. Results of a randomized phase III trial of mirabegron in patients with overactive bladder. J Urol. 2013;189:1388-95.

113. Nitti VW, Khullar V, van Kerrebroeck P, Herschorn S, Cambronero J, Angulo JC, et al. Mirabegron for the treatment of overactive bladder: a prespecified pooled efficacy analysis and pooled safety analysis of three randomised, double-blind, placebocontrolled, phase III studies. Int J Clin Pract. 2013;67:619-32.

114. Malik M, van Gelderen EM, Lee JH, Kowalski DL, Yen M, Goldwater R, et al. Proarrhythmic safety of repeat doses of mirabegron in healthy subjects: a randomized, double-blind, placebo-, and active-controlled thorough QT study. Clin Pharmacol Ther. 2012;92:696-706.

115. Amarenco G, Ismael SS, Even-Schneider A, Raibaut P, Demaille-Wlodyka S, Parratte B, et al. Urodynamic effect of acute transcutaneous posterior tibial nerve stimulation in overactive bladder. J Urol. 2003;169:2210-5.

116. Berghmans LC, Hendriks HJ, De Bie RA, van Waalwijk van Doorn ES, Bø K, van Kerrebroeck PE. Conservative treatment of urge urinary incontinence in women: a systematic review of randomized clinical trials. BJU Int. 2000;85:254-63. 
117. Finazzi-Agrò E, Petta F, Sciobica F, Pasqualetti $P$, Musco $S$, Bove P. Percutaneous tibial nerve stimulation effects on detrusor overactivity incontinence are not due to a placebo effect: a randomized, double-blind, placebo controlled trial. J Urol. 2010;184:2001-6.

118. Peters KM, Carrico DJ, MacDiarmid SA, Wooldridge LS, Khan AU, McCoy CE, et al. Sustained therapeutic effects of percutaneous tibial nerve stimulation: 24-month results of the STEP study. Neurourol Urodyn. 2013;32:24-9.

119. Onal M, Ugurlucan FG, Yalcin O. The effects of posterior tibial nerve stimulation on refractory overactive bladder syndrome and bladder circulation. Arch Gynecol Obstet. 2012;286:1453-7.

120. Govier FE, Litwiller S, Nitti V, Kreder KJ Jr, Rosenblatt P. Percutaneous afferent neuromodulation for the refractory overactive bladder: results of a multicenter study. J Urol. 2001;165:1193-8.

121. Biemans JM, van Balken MR. Efficacy and effectiveness of percutaneous tibial nerve stimulation in the treatment of pelvic organ disorders: a systematic review. Neuromodulation. 2013;16:25-33;discussion 33.

122. Burton C, Sajja A, Latthe PM. Effectiveness of percutaneous posterior tibial nerve stimulation for overactive bladder: a systematic review and meta-analysis. Neurourol Urodyn. 2012;31:1206-16.

123. Gaziev G, Topazio L, lacovelli V, Asimakopoulos A, Di Santo A, De Nunzio C, et al. Percutaneous Tibial Nerve Stimulation (PTNS) efficacy in the treatment of lower urinary tract dysfunctions: a systematic review. BMC Urol. 2013;13:61.

124. Marchal C, Herrera B, Antuña F, Saez F, Perez J, Castillo E, et al. Percutaneous tibial nerve stimulation in treatment of overactive bladder: when should retreatment be started? Urology. 2011;78:1046-50.

125. Arrabal-Polo MA, Palao-Yago F, Campon-Pacheco I, Martinez-Sanchez M, Zuluaga-Gomez A, Arrabal-Martin M. Clinical efficacy in the treatment of overactive bladder refractory to anticholinergics by posterior tibial nerve stimulation. Korean J Urol. 2012;53:483-6.

126. Yoong W, Shah P, Dadswell R, Green L. Sustained effectiveness of percutaneous tibial nerve stimulation for overactive bladder syndrome: 2-year follow-up of positive responders. Int Urogynecol J. 2013;24:795-9.

127. Flynn MK, Amundsen CL, Perevich M, Liu F, Webster GD. Outcome of a randomized, double-blind, placebo controlled trial of botulinum A toxin for refractory overactive bladder. J Urol. 2009;181:2608-15.

128. Dmochowski R, Chapple C, Nitti VW, Chancellor M, Everaert K, Thompson C, et al. Efficacy and safety of onabotulinumtoxinA for idiopathic overactive bladder: a double-blind, placebo controlled, randomized, dose ranging trial. J Urol. 2010;184:2416-22.
129. Chapple C, Sievert KD, MacDiarmid S, Khullar V, Radziszewskı $\mathrm{P}$, Nardo C, et al. OnabotulinumtoxinA $100 \mathrm{U}$ significantly improves all idiopathic overactive bladder symptoms and quality of life in patients with overactive bladder and urinary incontinence: a randomised, double-blind, placebocontrolled trial. Eur Urol. 2013;64:249-56.

130. Nitti VW, Dmochowski R, Herschorn S, Sand P, Thompson $\mathrm{C}$, Nardo C, et al. OnabotulinumtoxinA for the treatment of patients with overactive bladder and urinary incontinence: results of a phase 3 , randomized, placebo controlled trial. $J$ Urol. 2013;189:2186-93.

131. Denys P, Le Normand L, Ghout I, Costa P, ChartierKastler E, Grise P, et al. Efficacy and safety of low doses of onabotulinumtoxinA for the treatment of refractory idiopathic overactive bladder: a multicentre, double-blind, randomised, placebo-controlled dose-ranging study. Eur Urol. 2012;61:520-9.

132. Kuo HC, Liao CH, Chung SD. Adverse events of intravesical botulinum toxin a injections for idiopathic detrusor overactivity: risk factors and influence on treatment outcome. Eur Urol. 2010;58:919-26.

133. Rovner E, Kennelly M, Schulte-Baukloh H, Zhou J, Haag-Molkenteller C, Dasgupta P. Urodynamic results and clinical outcomes with intradetrusor injections of onabotulinumtoxinA in a randomized, placebo-controlled dose-finding study in idiopathic overactive bladder. Neurourol Urodyn. 2011;30:556-62.

134. Kanagarajah P, Ayyathurai R, Caruso DJ, Gomez C, Gousse AE. Role of botulinum toxin-A in refractory idiopathic overactive bladder patients without detrusor overactivity. Int Urol Nephrol. 2012;44:91-7.

135. Granese R, Adile G, Gugliotta G, Cucinella G, Saitta S, Adile B. Botox $(\circledast)$ for idiopathic overactive bladder: efficacy, duration and safety. Effectiveness of subsequent injection. Arch Gynecol Obstet. 2012;286:923-9.

136. Sahai A, Dowson C, Khan MS, Dasgupta P; GKT Botulinum Study Group. Repeated injections of botulinum toxin-A for idiopathic detrusor overactivity. Urology. 2010;75:552-8.

137. Khan S, Kessler TM, Apostolidis A, Kalsi V, Panicker J, Roosen $A$, et al. What a patient with refractory idiopathic detrusor overactivity should know about botulinum neurotoxin type a injection. J Urol. 2009;181:1773-8.

138. Mohee A, Khan A, Harris N, Eardley I. Long-term outcome of the use of intravesical botulinum toxin for the treatment of overactive bladder (OAB). BJU Int. 2013;111:106-13.

139. Veeratterapillay R, Harding C, Teo L, Vasdev N, Abroaf $A$, Dorkin TJ, et al. Discontinuation rates and interinjection interval for repeated intravesical botulinum toxin type A injections for detrusor overactivity. Int J Urol. 2014;21:175-8.

140. Santos-Silva A, da Silva CM, Cruz F. Botulinum toxin treatment for bladder dysfunction. Int J Urol. 2013;20:956-62. 
141. Leong RK, De Wachter SG, Nieman FH, de Bie RA, van Kerrebroeck PE. PNE versus 1st stage tined lead procedure: a direct comparison to select the most sensitive test method to identify patients suitable for sacral neuromodulation therapy. Neurourol Urodyn. 2011;30:1249-52.

142. Marcelissen T, Leong R, Serroyen J, van Kerrebroeck $\mathrm{P}$, de Wachter $\mathrm{S}$. Is the screening method of sacral neuromodulation a prognostic factor for long-term success? J Urol. 2011;185:583-7.

143. Spinelli M, Giardiello G, Gerber M, Arduini A, van den Hombergh U, Malaguti S. New sacral neuromodulation lead for percutaneous implantation using local anesthesia: description and first experience. J Urol. 2003;170:1905-7.

144. Amundsen CL, Webster GD. Sacral neuromodulation in an older, urge-incontinent population. Am J Obstet Gynecol. 2002;187:1462-5.

145. Yazdany T, Bhatia N, Nguyen J. Determining outcomes, adverse events, and predictors of success after sacral neuromodulation for lower urinary disorders in women. Int Urogynecol J. 2011;22:1549-54.

146. Noblett K, Siegel S, Mangel J, Griebling TL, Sutherland SE, Bird ET, et al. Results of a prospective, multicenter study evaluating quality of life, safety, and efficacy of sacral neuromodulation at twelve months in subjects with symptoms of overactive bladder. Neurourol Urodyn. 2016;35:246-51.

147. Groen LA, Hoebeke P, Loret N, Van Praet C, Van Laecke E, Ann $\mathrm{R}$, et al. Sacral neuromodulation with an implantable pulse generator in children with lower urinary tract symptoms: 15year experience. J Urol. 2012;188:1313-7.

148. Janknegt RA, Hassouna MM, Siegel SW, Schmidt RA, Gajewski JB, Rivas DA, et al. Long-term effectiveness of sacral nerve stimulation for refractory urge incontinence. Eur Urol. 2001;39:101-6.
149. van Kerrebroeck PE, van Voskuilen AC, Heesakkers JP, Lycklama á Nijholt AA, Siegel S, Jonas U, et al. Results of sacral neuromodulation therapy for urinary voiding dysfunction: outcomes of a prospective, worldwide clinical study. J Urol. 2007;178:2029-34.

150. Siegel SW, Catanzaro F, Dijkema HE, Elhilali MM, Fowler CJ, Gajewski JB, et al. Long-term results of a multicenter study on sacral nerve stimulation for treatment of urinary urge incontinence, urgency-frequency, and retention. Urology. 2000;56:87-91.

151. Peeters K, Sahai A, De Ridder D, Van Der Aa F. Long-term follow-up of sacral neuromodulation for lower urinary tract dysfunction. BJU Int. 2014;113:789-94.

152. Chartier-Kastler E, Ballanger P, Belas M, Biserte J, Corbel L, Gamé X, Grise P, et al. Sacral neuromodulation with InterStim ${ }^{\text {TM }}$ system: Results from the French national register. Prog Urol. 2011;21:209-17.

153. Angioli R, Montera R, Plotti F, Aloisi A, Montone E, Zullo MA. Success rates, quality of life, and feasibility of sacral nerve stimulation in elderly patients: 1-year follow-up. Int Urogynecol J. 2013;24:789-94.

154. Hijaz A, Vasavada SP, Daneshgari F, Frinjari H, Goldman $H$, Rackley R. Complications and troubleshooting of twostage sacral neuromodulation therapy: a single-institution experience. Urology. 2006;68:533-7.

155. Leong RK, De Wachter SG, van Kerrebroeck PE. Current information on sacral neuromodulation and botulinum toxin treatment for refractory idiopathic overactive bladder syndrome: a review. Urol Int. 2010;84:245-53.

156. Cameron AP, Anger JT, Madison R, Saigal CS, Clemens JQ; Urologic Diseases in America Project. Battery explantation after sacral neuromodulation in the Medicare population. Neurourol Urodyn. 2013;32:238-41.

Correspondence address: Jose Carlos Truzzi, MD

Escola Paulista de Medicina - EPM, Universidade Federal de São Paulo, Rua Dr. Oscar Monteiro de Barros, 617 / 141 São Paulo, SP, 05641-010, Brasil E-mail: jctruzzi@hotmail.com 